\title{
Aspects of Human Behaviour in Negotiation Process
}

\author{
Dan Săvescu ${ }^{1 *}$ \\ ${ }^{1}$ Transilvania University of Braşov, Romania
}

\begin{abstract}
Paper presents some aspects regarding negotiation human behaviour process. There are presented some ideas about entrepreneurship, negotiation being an important part of this "job", negotiating as art, negotiation for your own advantage, barriers of negotiation, objections' management, conclusions and references.
\end{abstract}

\section{Introduction}

One of the factors that makes the difference between a successful entrepreneur and an average entrepreneur is thinking.

A successful entrepreneur understands that the world is full of great possibilities and ideas. A successful entrepreneur understands that failure is a step towards even greater success, and not just an obstacle to overcome. A good entrepreneur needs to know how to develop creative ideas. Creativity is present in every lucrative success. A good entrepreneur needs to know quickly to make the right decisions. It has been discovered that the speed of decision-making is a feature of many millionaires. Business thinker James Allen [1] said, "Your previous thoughts brought you to where you are today. Tomorrow you will be where your thoughts will take you today. "And indeed, at work, the quality of the way of thinking determines the quality of the gain.

Entrepreneurship is the basis for a successful business in the long run. In the process of material exchanges between market players, there are exchanges, with already existing patterns, standards, requiring or offering products / technologies (these are TTO Technology to offer and TTR - Technology to request, known in EU policy, 2020). All these product exchanges are based on negotiation. In other words, negotiation is an integral part of the competitive entrepreneurial process.

\section{Negotiating as art}

As in every moment of our life we sell, we also negotiate something in any day. A leader will be put in a number of times in the face of a situation where he has to convince a manager of the need to allocate resources or the need for a certain decision. Also, a leader can be part of the team negotiating the customer contract or can lead negotiations with a raw material supplier or simply negotiate with a team member the assignment and the characteristics of tasks within the project. Negotiation is an organized social process, a set of techniques used by at least two partners to reach a consensus; it requires a dialogue, a permanent communication between the two sides in which it is sought (at least theoretically and declaratively) the avoidance of confrontations.

\section{What is negotiation?}

After François de Collieres (1716): the science of agreeing on the benefits and interests of the parties concerned.

Arthur Lall: a dispute resolved by peaceful means other than legal.

Smith Simpson: a part of the vast and complex managerial activity through which management promotes its own objectives.

F. Ikle: links the need for negotiation with the presence of conflicting interests that can be achieved through explicit proposals presented ably for the obvious purpose of reaching an agreement.

John Illich, in 1980, said that negotiation, in its purest form, is the intelligence opposed to another intelligence [2].

According to Gerhard I. Nierenberg, in his work "The Art of Negotiation" [1-3] "whenever people change ideas with the intention of changing relationships, whenever they prefer a deal, then they negotiate ... Negotiation is not led either to open or to limit a relationship, but form a new and different configuration. "

\section{The results of negotiation process}

The negotiation process is under the risk. It is hard to assume that "the home account matches the market one."

Any negotiation ends in one of four possible variants:

- Both sides have to lose;

- One part is worth winning, the other has to lose;

- Both sides have a win;

- No results - no positive or negative consequences.

The results in which both parties have to lose appear when none of them get what it needs or wants. One example: a customer wants to buy a card processing

\footnotetext{
* Corresponding author: dsavescu@unitbv.ro
} 
machine with the features. A vendor is presenting the machine at a price that was real with the one on the market. After a while, the buyer changes his mind and cancels the contract, moving on a more tempting offer. The seller lost a customer and the buyer purchased a non-performing machine, being in litigation, in court, with the seller. Therefore, the buyer lost the transaction, lost time, lost customers. Another example is related to disagreements between employer and union on wages. The end of the negotiation is loss-loss, the strikers did not get the salary increases, the company lost time, customers and money. Usually the failure is the poor preparation of the negotiation session, somewhat unprepared participants!

The second variant is interesting, it depends only on what part you are: winner or defeated. The taste of defeat is bitter, hard to bear, and it is hard to assume there will be a similar situation between the two, the buyer and the seller. One example: a client calls a bank for a short-term loan (60 days). Receives the credit but after 45 days the bank changes the terms of credit repayment (reasons, inflation, legislation, etc.). Being only a small loss, for the remaining days - 15 , the customer accepts the new conditions. The bank won, the client lost (as usual!). It's obvious that in a similar situation the client will not call that bank anymore.

The ideal outcome of the negotiation is mutual gain, basically both sides are pleased with this move. It is a pleasure to see satisfaction on the faces of the participants after finalizing the negotiations, the needs and goals of both parties are fulfilled. Negotiation is a cooperative action; it is not a game, in a good bargain, when everyone has a win.

In the fourth situation, the one of the null result, the parties, can be said to have lost time, were not sufficiently motivated or simply did not prepare for negotiation. These situations are often encountered at "rigid" positions in the negotiation process or do not accept that there is a "competitive market" with many actors involved in the same field.

\section{Negotiation itself}

Negotiation itself is a creative process that involves imagination, flexibility and rapid adaptability to the partner, how to think and act. All these involve a strategic culture that takes on several aspects: setting individual priorities and objectives, negotiating orientation or overall vision, finding change or replication solutions in a potentially dangerous situation.

Arsenal of questions used in negotiation:

- Investigation questions (clarification, details);

- Confirmation questions (verification, summary, rewording);

- Return questions (the question is answered with a question);

- Alternative false questions (control of discussion by limiting options);

- Questions to relaunch (diverting the discussion).

An efficient negotiation begins with answers to some questions like (Table 1):
Table 1. Questions of an efficient negotiation

\begin{tabular}{|c|c|}
\hline $\begin{array}{c}\text { Efficient } \\
\text { negotiation } \\
\text { bazed on } \\
\text { quetions }\end{array}$ & $\begin{array}{l}\text {-What do I want to get from the } \\
\text { negotiation? } \\
\text {-What does the partner / opponent } \\
\text { want to achieve? } \\
\text {-How can we both achieve our } \\
\text { interests? } \\
\text {-What does the man in front of me } \\
\text { want to know? } \\
\text {-What questions will I ask? } \\
\text {-What questions to ask? } \\
\text {-How will my partner react to my } \\
\text { questions? } \\
\text {-How can we reach consensus? }\end{array}$ \\
\hline
\end{tabular}

Major strategic decisions at the beginning or during the negotiation are the choice of an offensive or defensive strategy, a conciliatory attitude or, on the contrary, intransigence, an open or closed approach to the process, etc.

Information is also in the negotiation process the main instrument available to the negotiator. Going into the door of negotiations with "Lessons Made" is a sometimes decisive advantage in achieving the goals.

Another strong point is the ability to transpose instead of the one in front of you; Understanding your negotiating partner as to the motivations and constraints to which it is subject is another key factor in success. The "read" techniques of non-verbal signals are here at home. Even if their interpretation in an isolated context can lead to false ideas, most often a corroboration of these gestures and posts with "snapped" information from others can reveal aspects that make the difference between success and failure.

The way is to admit that:

- The one in front of us has a different reality from ours; - We can understand the other's point of view;

- The idea that "different" does not mean "worse" or "bad".

In the negotiation, the actual submission of an initial offer must be made firmly, without reservations, hesitations or justifications of any kind. It's more convenient to submit your offer after you hear one of your partners. Every aspect of the offer must be realistically addressed and there is the possibility of its real argument. Opening bids must be the best for their point of view (setting high goals leads to better results) with rigorous and solid arguments. Successful negotiators make much less concessions than their opponents because of an indispensable quality: they are unpredictable in terms of concession size. Also a competent negotiator responds to the offer of others through clarifications, not through justifications.

The features of negotiating offers in order to achieve maximum satisfaction are:

- each item of the offer received is analysed;

- no opinions or reasons are speculated;

- does not contradict directly, openly;

- the answers received will be noted before commenting on them;

- its own position does not occur very quickly; 
- does not immediately come into direct problem analysis;

- it does not advance on a wide front.

\section{Negotiating for your own advantage}

If you can not convince them, get them confused.
(Murphy)

Succession of problems in negotiation process, in case of looking for your own advantage is presented in Table 2 .

Table 2. Succession of problems

\begin{tabular}{c|l|}
\cline { 2 - 3 } 1 & $\begin{array}{l}\text { It starts with a problem that is not very } \\
\text { important to us, from which concessions can be } \\
\text { made and the willingness to make concessions. }\end{array}$ \\
\hline 2 & $\begin{array}{l}\text { Another problem is equally unimportant, to test } \\
\text {,their negotiation" mode and to analyse the } \\
\text { concessions they are willing to make. }\end{array}$ \\
\hline 3 & $\begin{array}{l}\text { The critical issue for us (but which will not be } \\
\text { presented) is being addressed for which we will } \\
\text { seek special concessions from others. }\end{array}$ \\
\hline 4 & $\begin{array}{l}\text { There are other major, then minor problems. } \\
\text { For the end, a minor problem for which } \\
\text { significant concessions are granted is retained. }\end{array}$ \\
\cline { 2 - 3 }
\end{tabular}

\section{Barriers to negotiation}

The main obstacles to negotiation are represented by:

- Frustration and anger;

- Perceiving negotiation as a win-loss game ("What I earn will have to lose you and vice versa");

- Clear distinctions of status and power between the two negotiators.

The worst negotiation is done when you are frustrated or angry ... Ancestral wisdom indicates that nothing in this world is catastrophic for at least two reasons:

- Most events are not as serious as we think;

- if something really serious happened by going out of the way we make it even worse.

Frustration is the situation where you do not get what you want or when you get forced what you did not want. Frustration does not necessarily lead to disorder and aggression (if we know how to control it), but it often generates anger. Angry people actually conceal the fear of failure, and anger raises a reaction to anger (for example, a dictatorial attitude generates frustration and anger). Anger can also be born out of self-pity.

Anger is a self-healing and self-sustaining process. The first phase is because I want something. Not getting what I wanted to become frustrated. Then I come to the idea that it is terrible that I did not get that "something" and end up in a depression phase. At this stage you have to look for guilty ... every time someone else is to blame; that one is bad because his attitude led me to depression and must be punished. How can I punish him? Simply: by shouting at him, wounding him, wiping him, watching his balance and dignity, etc. Accusation (personal or other) has an essential role in the appearance of anger.
Generally, the three reasons for inappropriate behaviour are: stupidity, ignorance, and disorder. If we consider any unwanted behaviour as a natural result of one of these three reasons, we will certainly be able to avoid (at least partially) anger. People's selfishness is a fact that can be treated as a simple and natural meteorological phenomenon: they cannot blame the phenomenon but can do something to avoid its consequences.

How can we avoid the emergence of nervousness in the negotiations? Albert Ellis [2] suggests an answer to the above question: "treats with gratitude those who act ugly with you; so they become ridiculous. " By controlling your anger you force the other not to break into a conflict; the Bible parable tells us "after a slap that gives you back and the other cheek". If you are attacked by insulting remarks, becoming more courteous, you can create consternation through your behaviour and even a radical change in the attitude of the one in front of you who is "suddenly" quiet.

The harmful consequences of anger are clear: it increases frustration, prevents you from solving problems, it is a poor example in the eyes of the collaborators and can lead to physical illness.

Combating rage starts from accepting the idea that we are upset ourselves because of the irrational ideas that we impose on ourselves. We can counter anger by learning how to identify these irrational thoughts and what to replace them.

Affective - rational anger therapy has some clear features, as seen in Table 3:

Table 3. Anger therapy

\begin{tabular}{|c|c|}
\hline $\begin{array}{c}\text { Do not be } \\
\text { discouraged }\end{array}$ & $\begin{array}{c}\text { When you try to reject the } \\
\text { neurotic ideas and still feel angry, } \\
\text { continue to discuss them with } \\
\text { yourself until you stop believing } \\
\text { in them. }\end{array}$ \\
\hline $\begin{array}{c}\text { Discipline } \\
\text { yourself }\end{array}$ & $\begin{array}{c}\text { You have to be able to shut up } \\
\text { when it is very hard not to say } \\
\text { something to someone }\end{array}$ \\
\hline $\begin{array}{c}\text { You do not } \\
\text { have to } \\
\text { aggravate } \\
\text { the } \\
\text { situation }\end{array}$ & $\begin{array}{c}\text { The greatest suffering is not } \\
\text { caused by others, but by what we } \\
\text { allow our own anguish; should be } \\
\text { taken from the "look what they } \\
\text { did" approach to the "look what I } \\
\text { did from what they did to me" }\end{array}$ \\
\hline
\end{tabular}

To perceive negotiation as a place where there is a defeated and a winner does not mean negotiation or manipulation, it is to make the one in front of you have a totally inappropriate attitude with its principles and values. In the short term, such an approach seems beneficial, because you can get the best price or you can intimidate and annoy the "opponent"; but in the long run you have won a battle, but you will never win the war. The "defeated" often has profound resentment and is, in most cases, really disgusted with the "winner" negotiation. Especially when handling techniques are applied in a constant way to collaborators this attitude will have a demotivating effect; in the medium and long term (from just over 2-3 months) your collaborators will leave you, the team spirit begins to become a declared but unapplied thing and the project begins to squeak ... 
When negotiating a team leader from Section 2 with the group's general manager, who is surrounded by 5 counsellors, 2 lawyers, and 3 executives, the outcome of the negotiation seems to be out of the box; in order not to impose solutions and to find the best option to convince everyone involved, it is necessary for the negotiations to take place between persons at a relatively close hierarchical level.

\section{Attitude to objections}

Objections must be allowed to appear on the surface; they need to be searched for as a source of information about the person, his needs and his intellectual capacity. In addition, the partner appreciates the other's interest in his problems. A good negotiator is not afraid of objections because, through a good argument, they lose their strength; the negotiator will gain the prestige in the partner's eyes.

One of the basic rules of diplomacy is to always allow the partner the possibility of an honourable exit ("Allow the deceased to be worthy" - Fisher said); this behaviour leaves the door open for future communication. It should not be interrupted but listened with attention and respect and the answers given should not immediately follow the question but after a few seconds, even if you do not need to meditate. Trust, do not want to have the last word at all costs, do not panic or dramatize. A crisp attitude, a serious tone and a long response reflect in the partner's mind another dimension of the problem, which is often not true.

A nodal point in the objection technique is the detection of false objections; generally a true, "honest" objection hides a need for additional information. False objections are those that rise in a shameless way.

When you get a false objection you can answer in several ways:

- Silence - just let a tense silence wait over your conversation while staying firm and insistent on your partner; most of the time it will yield and withdraw or reformulate its objection (here is the principle of "who speaks first, loses")

- You can ask for additional clarifications, especially if you are not sure that this is a mischievous objection; by clarifying the objection and by considering the logic of argumentation, you can see whether it is a sincere or not objection.

- You can use the hanging technique - the words: "If you respond to this objection, we will finish the discussion (contract)?". In the negotiation process, when seeking a solution, each party is required to make concessions.
The courtesy rules assume very strictly that a concession made by one of the parties is followed by a concession of the same level made by the other party. It is advisable that the pace of concessions made be similar - it begins by giving up a little more then more and more to end concessions when the other side does not respond in the same rhythm. Another rule is not to make concessions if they are not needed.

\section{Conclusions}

A solid basis in the negotiation process is trust. The more honesty, integrity and credibility, the more trust your business partner has, the more successful the negotiation is. If for some reason your partner considers you inferior, unreliable, it is difficult to obtain even minor concessions. When it comes to gaining someone's trust, actions say more than words. Here is a succession of things on which to build trust in the negotiating partner.

- Demonstrate your competence;

- Make sure that the non-verbal signals you send fit with your statements;

- maintain a professional image;

- Communicate your good intentions

- Do what you say you want to do

- Go beyond the conventional relationship;

- Listen;

- Communicate as much as possible;

- Discuss what is not to be discussed;

- Provides accurate information without hidden thoughts;

- Be honest, even if it costs you something;

- Be patient;

- Attention to fairness;

- Negotiate for abundance and not for poverty;

- Assume calculated risks.

"You never get what you deserve, you get what you negotiate" (Bill Scott)

\section{References}

1. P. B. Stark, J. Flaherty. Practical guide in negotiation. ED Amaltea (2008)

2. A. Pekar Lempereur, A. Colson. Méthode de négociation. DUNOD, Paris (2004)

3. D. Săvescu. Project management. ED LUXLIBRIS, Braşov (2017) 